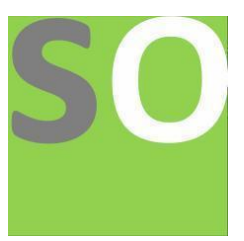

Article title: A Study of Emotional Intelligence of Electrical Engineering students in Dire Dawa University Ethiopia Authors: Mustefa Jibril[1]

Affiliations: Dire Dawa University, Dire Dawa, Ethiopia[1]

Orcid ids: 0000-0002-3165-2410[1]

Contact e-mail: mustefazinet1981@gmail.com

License information: This work has been published open access under Creative Commons Attribution License $\mathrm{http}: / / c r e a t i v e c o m m o n s . o r g / l i c e n s e s / b y / 4.0 /$, which permits unrestricted use, distribution, and reproduction in any medium, provided the original work is properly cited. Conditions, terms of use and publishing policy can be found at https://www.scienceopen.com/.

Preprint statement: This article is a preprint and has not been peer-reviewed, under consideration and submitted to ScienceOpen Preprints for open peer review.

DOI: 10.14293/S2199-1006.1.SOR-.PPTOAYC.v1

Preprint first posted online: 27 June 2021

Keywords: Emotional intelligence, Industrial control engineering, Power system engineering, Communication engineering 


\title{
A Study of Emotional Intelligence of Electrical Engineering students in Dire Dawa University Ethiopia
}

\author{
Mustefa JIBRIL \\ School of Electrical \& Computer Engineering, Dire Dawa Institute of Technology, Dire Dawa, \\ Ethiopia \\ mustefa.jibril@ddu.edu.et
}

\begin{abstract}
The present study was carried out to study the emotional intelligence of Electrical Engineering students in Dire Dawa University Ethiopia. The sample for the study was 90 (30 Industrial control engineering streams, 30 Power system engineering streams, and 30 Communication engineering streams) randomly selected from Dire Dawa university, school of electrical and computer engineering. A sample scale was employed for the data collection and a t-test was employed for the analysis of data. The outcome of the study shows that Industrial control engineering and Power system engineering students do not differ significantly on various dimensions of Emotional intelligence and Industrial control engineering and Communication engineering students do not differ significantly on various dimensions of Emotional intelligence and Power system engineering and Communication engineering students differ significantly on various dimensions of Emotional intelligence.
\end{abstract}

Keywords: Emotional intelligence, Industrial control engineering, Power system engineering, Communication engineering

\section{Introduction}

Emotional intelligence (otherwise known as " the emotional factor or the editor is the ability to understand, use, and effectively manage emotions, to relieve stress, communicate effectively, empathize with others, overcome challenges, and have conflict resolution. The importance of emotional intelligence helps you to build long-term relationships and the achievement of academic and work performance, and the achievement of your goals and objectives. It can also help you to communicate your feelings, and his goal is to get to the action and make a wellinformed decision on what's most important to you.

The importance of emotional intelligence (EI), often defined as the ability to see, use, understand, and manage emotions. People with high emotional intelligence can see their own and other people's emotions, and use emotional information to guide thinking and behavior, to identify the various emotions and consequently, and to the adaptation of the emotions according to the situation. [1]-[3]

Emotional intelligence is seen as an effective way to identify, monitor, and expression of emotion. and also, to identify and understand the nature of the results. In addition, there is a degree of the unit can absorb these emotions and thoughts, and strategically use them to achieve the alignment of goals, and to effectively organize the negative and positive emotions and the best of possibly of others [4]. In [5] describe a suitable representation of the importance of emotional intelligence. He points out that the benefits of emotional intelligence to motivate people, to help in the control of impulsivity, and to the right, and the turn-on of the people are in situations where they face barriers to success.

Goleman's model identifies four key dimensions of emotional intelligence: the first dimension of self-awareness is the ability to recognize the emotions, and the impact of the units using these 
emotions, to make a decision. The second dimension of self-management is the control of emotion, motivation, and will to adapt to changing circumstances. In the third dimension, social awareness refers to the ability to sense, understand, and deal with the emotion's others are in the process of social interaction in various life situations. The fourth dimension regards customer relationship management, which is designed to inspire and have an impact on the development of other people in the process of conflict management [6].

Different types are designed to measure EI. The feature model that focuses on self-reported behavioral and practical skills. [7] The skill model that focuses on the ability of a person to research the emotional details he or she has used to navigate a social space. [5] Goleman's original model can now be considered a hybrid model that combines what has been modeled separately such as EI capability and trait EI. Recent research has focused on emotional awareness, which refers to the provision of emotional states based on the perception of visual and audible non-verbal cues. [6] In addition, neurosurgeons have sought to reveal neural mechanisms of emotional intelligence. [8]

Studies have shown that people with high EI have greater mental health, job performance, and leadership skills, although no causal relationship has been shown. EI is often associated with empathy because it involves a person who connects his or her experience with that of others. Since its popularity in recent decades, ways to improve EI have become increasingly sought after by people who want to become more successful leaders [9].

\section{Material and Methods}

\section{Sample:}

The sample for the study was 90 (30 Industrial control engineering streams, 30 Power system engineering streams, and 30 Communication engineering streams) randomly selected from Dire Dawa university, school of electrical and computer engineering.

\section{Result and Discussion}

Table 1 Mean Comparison of Industrial control engineering and Power system engineering Students on various dimensions of Emotional Intelligence.

\begin{tabular}{|c|c|c|c|c|}
\hline Group & Number & Mean/SD & ' $\mathbf{t}$ ' Value & $\begin{array}{c}\text { Level of } \\
\text { Significant }\end{array}$ \\
\hline Industrial control & 30 & $69.13 / 13.23$ & \multirow{2}{*}{3.76} & $\begin{array}{c}\text { Significant at } \\
0.01\end{array}$ \\
\hline Power system & 30 & $82.46 / 14.26$ & & \\
\hline
\end{tabular}

Table 1 shows the mean comparison of Industrial control and Power system students on various dimensions of Emotional Intelligence. Table 1 reveals that the two groups i.e. Industrial control and Power system students differ significantly on various dimensions of Emotional Intelligence on ( 0.01 level) it further deputies that Power system students possess a higher capacity for introspection and the ability to recognize themselves as on individual separate from the environment and other individuals, the ability to understand and share the feelings of another (empathy), ability to do what needs to be done without influence from other people or situations than Industrial control students.

Table 2. Mean Comparison of Industrial control and Communication Students on various dimensions of Emotional Intelligence. 


\begin{tabular}{|c|c|c|c|c|}
\hline Group & Number & Mean/SD & ' $\mathbf{t}$ ' Value & $\begin{array}{c}\text { Level of } \\
\text { Significant }\end{array}$ \\
\hline Industrial control & 30 & $69.13 / 13.23$ & 1.20 & $\begin{array}{c}\text { Not- } \\
\text { Significant }\end{array}$ \\
\hline Communication & 30 & $72.96 / 14.26$ & 1.20 \\
\hline
\end{tabular}

Table 2 shows the mean comparison of Industrial control and Communication Students on various dimensions of Emotional Intelligence. Table 2 reveals that the two groups i.e. Industrial control and Communication Students do not differ significantly on various dimensions of Emotional Intelligence. It further depicts that two groups have some self-awareness, empathy, self-motivate, emotional stability, value orientation, altruistic behavior, commitment.

Table 3. Mean Comparison of Power system and Communication Students on various dimensions of Emotional Intelligence.

\begin{tabular}{|c|c|c|c|c|}
\hline Group & Number & Mean/SD & 't' Value & Level of Significant \\
\hline Power system & 30 & $82.46 / 14.26$ & \multirow{2}{*}{2.86} & Significant at 0.01 \\
\hline Communication & 30 & $72.96 / 14.26$ & & \\
\hline
\end{tabular}

Table 3 reveals that the two groups i.e. Power system and Communication Students differ significantly on various dimensions of Emotional Intelligence on ( 0.01 level) it further depicts that Power system students are in a state of being able to have the appropriate feeling about the common experiences and being able to act rationally, they have the quality of being honest and having strong moral principles and moral uprightness Power system students can bind themselves intellectually or emotionally to a course of action they show unselfish concern for the welfare of others as compared to Communication students.

\section{Conclusion}

The main objectives of the study were to measure the Emotional Intelligence of Electrical Engineering (Industrial control engineering stream, Power system engineering stream, and Communication engineering stream) Students on various dimensions of Emotional Intelligence. The sample for the present study comprised of 90 Dire Dawa university, school of electrical and computer engineering students of which 30 were Industrial control engineering stream, 30 was Power system engineering stream and 30 were Communication engineering stream Students. The data were analyzed by applying the ' $t$ ' test.

\section{The Main Conclusions of the Study are as under:}

1. Power system engineering stream students have better self-awareness, empathy, selfmotivate, emotional stability, integrity, commitment than Science Students.

2. Industrial control engineering and Communication engineering stream students do not differ significantly on various dimensions of Emotional Intelligence.

3. Power system engineering stream Students have better managing relations selfdevelopment, value-oriented and altruistic behavior than Communication engineering stream students.

\section{References}


[1].Hamzah, S. R. A., Kai Le, K., \& Musa, S. N. S. (2021). The mediating role of career decision self-efficacy on the relationship of career emotional intelligence and self-esteem with career adaptability among university students. International Journal of Adolescence and Youth, 26(1), 83-93.

[2].Hussein Bakr, M. T. (2021). Fear of love and its Relationship to the Emotional Intelligence of University Students. Zanco Journal of Humanity Sciences, 25(1), 155-167.

[3].Khan, M., Minbashian, A., \& MacCann, C. (2021). College students in the western world are becoming less emotionally intelligent: A cross - temporal meta - analysis of trait emotional intelligence. Journal of Personality.

[4].Pumaleque, A. A. P., Arbulu, A. C. A., Calle, C. A. P., \& Gutierrez, F. H. P. (2021). Emotional Intelligence Model to Improve Resilience in University Students. Journal of Contemporary Issues in Business and Government Vol, 27(2).

[5].Rosales-Pérez, A. M., Fernández-Gámez, M. A., Torroba-Díaz, M., \& Molina-Gómez, J. (2021). A Study of the Emotional Intelligence and Personality Traits of University Finance Students. Education Sciences, 11(1), 25.

[6]. Owoseni, O. O., Mayungbo, O. A., Olatunji, O. A., \& Okunola, O. E. (2021). Will Emotional Intelligence Predict Entrepreneurial Intentions?. North American Journal of Psychology, 23(1).

[7].Dawda, D., \& Hart, S. D. (2000). Assessing emotional intelligence: Reliability and validity of the Bar-On Emotional Quotient Inventory (EQ-i) in university students. Personality and individual differences, 28(4), 797-812.

[8].Depape, A. M. R., Hakim-Larson, J., Voelker, S., Page, S., \& Jackson, D. L. (2006). Selftalk and emotional intelligence in university students. Canadian Journal of Behavioural Science/Revue Canadienne des sciences du comportement, 38(3), 250.

[9].Extremera, N., \& Fernández-Berrocal, P. (2006). Emotional intelligence as a predictor of mental, social, and physical health in university students. Spanish Journal of Psychology, $9(1), 45$. 